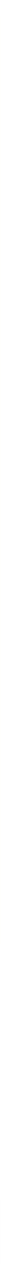





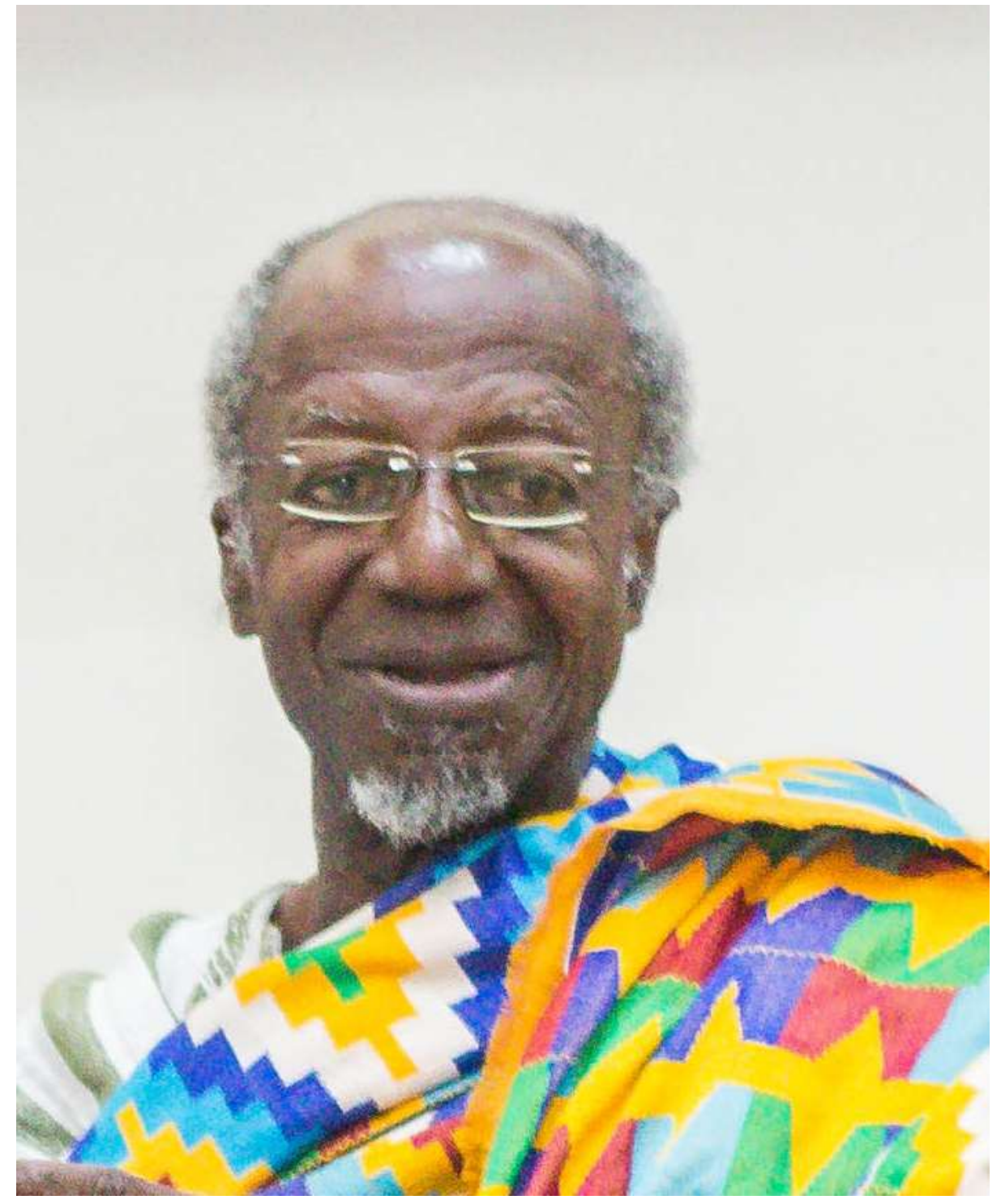
PROFESSOR ATTA GYAMFI BRITWUM 


\section{THE BILINGUAL LITERARY JOURNAL OF THE FACULTY OF ARTS UNIVERSITY OF CAPE COAST}

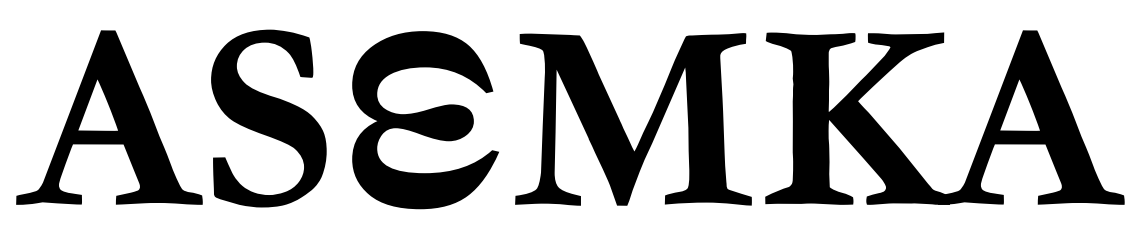

NUMBER 10

SEPTEMBER 2020

\section{EDITORIAL COMMITTEE}

Editor-in-Chief: $\quad$ Prof. Samuel Awuah-Nyamekye (Ph.D.)

Editor: $\quad$ Prof. Mawuloe Koffi Kodah (Ph.D.)

Associate Editors: Dr. Samuel Kwesi Nkansah

Dr. Mrs. Theresa Addai Munumkum

Dr. Isaac Mwinlaaru

Business Editor: Rev. Sr. Dr. Matilda Alice Nsiah

\section{EDITORIAL STAFF}

Mr. Stephen Owusu-Amoh

Mr. Isaac Kweku Grantson

\section{EDITORIAL ADVISORS}

Prof. Kwadwo Opoku-Agyemang, University of Cape Coast.

Prof. Joseph B. A. Afful, University of Cape Coast.

Prof. Raymond N. Osei, University of Cape Coast.

Prof. Richard V. Cudjoe, University of Cape Coast. 
Prof. Victor K Yankah, University of Cape Coast.

Dr. Mousa Traore, University of Cape Coast.

\section{ACKNOWLEDGEMENTS}

We acknowledge the contribution of the underlisted members of the Department of French who did preliminary editorial work on the papers:

Dr. Anthony Y.M. De-Souza (Chairman)

Prof. Raymond N. Osei

Prof. Mawuloe K. Kodah

Dr. Sylvester P. Krakue

Mr. Ofosu Addo-Danquah

Mr. Micheal Donkoh (Secretary)

\section{SUBSCRIPTION}

Assmka is published twice in the Academic year by the Faculty of Arts, University of Cape Coast. The annual out-of-Ghana subscription rate, including air-postage, is US\$29 for individuals, and US\$ 59 for institutions and libraries. Single issue rate for individuals is US\$18. Claims for copies not received must be made within three (3) months following an issue's publication. Correspondence should be addressed to:

The Editor, Assmka

Department of French

Faculty of Arts

College of Humanities and Legal Studies

University of Cape Coast

Cape Coast

Ghana, West Africa

Email: asemkajournal@ucc.edu.gh

\section{ADVERTISING}

Advertising rate, size specifications and related information are available upon request. Please, contact the General Editor for more information.

\section{SUBMISSIONS}

Ascmka is an internationally-refereed journal of the Humanities. It publishes scholarly and imaginative articles in Literature, Language, and Culture generally, including, Orature, Film, Theatre, Music and Art. Essays, Interviews, Book Reviews, Poetry, Short Prose Fiction and Drama are welcome. Submitted manuscripts, in English and French, must be prepared in accordance with the most recent of APA or MLA style manual, where 
applicable. The author's identity and address may appear only on the coverpage and nowhere else within the submitted manuscript. All manuscripts should be submitted electronically through:

asemkajournal@ucc.edu.gh

Manuscript will be duly acknowledged within two (2) months of receiving them. Individuals whose works are accepted for publication may provide Assmka with a brief bio-data. The Editors cannot be held liable for lost or damaged manuscripts. Material published by Assmka does not necessarily represent the views of the Journal's Editors, Staff, Financial Supporters or the University of Cape Coast and its affiliates. These parties disavow any legal responsibility related to all submitted material.

\section{BACK ISSUES}

Back issues of Ascmka that are in stock may be ordered from the Editor at US\$20 per copy.

\section{GRANT SUPPORT}

Assmka is funded through grants from the Office of the Dean, Faculty of Arts; the Publications' Board; and the Office of the Vice-Chancellor, University of Cape Coast, Cape Coast, Ghana.

No part of this Journal may be reproduced, stored in a retrieval system, or transmitted in any manner whatsoever without express permission from the Editors, except in the case of brief quotations embodied in critical Articles and Reviews.

Copyright (C2020 by The Editors and The Faculty of Arts, University of Cape Coast. The cover and page design elements were inspired by the Adinkra symbols of Ghana. 


\section{DEDICATION \\ PROFESSOR ATTA GYAMFI BRITWUM}

Professor Britwum is a man of many parts. He is as much at home with Marxist Economic Theory and Feminist Sociological Thoughts, as he is with French and Francophone Literatures. He is a great teacher and Administrator of international acclaim. The Editors dedicate this special issue of Ascmka to his honour. 


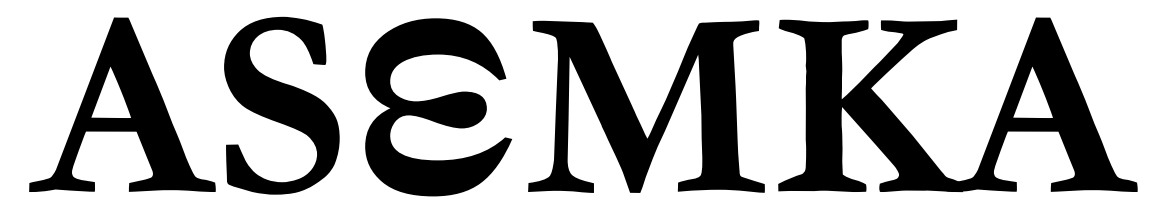

NUMBER 10

SEPTEMBER 2020 


\section{CONTENTS}

$\begin{array}{llll}\text { Editorial Committee } & \sim & \sim & \sim i i \\ \text { Editorial Staff } & \sim & \sim & \sim i i \\ \text { Editorial Advisors } & \sim & \sim & \sim i i \\ \text { Acknowledgements } & \sim & \sim & \sim i i i \\ \text { Subscription } & \sim & \sim & \sim i i i \\ \text { Advertising } & \sim & \sim & \sim i i i \\ \text { Submissions } & \sim & \sim & \sim i i i \\ \text { Back Issues } & \sim & \sim & \sim i v \\ \text { Grant Support } & \sim & \sim & \sim i v \\ \text { Dedication } \sim & \sim & \sim & \sim \\ \text { Foreword } \sim & \sim & \sim & \sim x \\ \text { Assmka: Editorial } & \sim & \sim & x i-x v i i\end{array}$

Articles

First Section - French

Britwum, A. G.

Insuffisances Théoriques Des Damnés De La Terre De

Frantz Fanon

$\sim$

$\sim 2-15$

Kodah, M. K.

Disculpation de Dieu dans le malheur des hommes:

Une lecture critique de Gouverneurs de la rosée de

Jacques Roumain $\sim \sim \sim 16-31$

Addo-Danquah, $O$.

Le récit de pensées: Une analyse comparative de Vol de nuit d'Antoine de Saint-Exupéry et La Condition humaine d'André Malraux

Kodah, M. K. \& Togoh, A. A. X.

Réactions des femmes face au conflit de genre dans C'est le soleil qui m'a brûlée et Tu t'appelleras Tanga de Calixthe Beyala

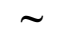

$\sim$

$\sim \quad 45-59$ 
Kudi, M. D.

La Littérature francophone face aux médias de télécommunication : Une nouvelle dynamique de la création romanesque, le cas de L'Énigme de retour et Tout bouge autour de moi de Dany Laferrière $\sim \quad$ 60-72

Gli, $M$.

Les faces du bonheur dans Vol de nuit d'Antoine de Saint-Exupéry $\sim \sim 73-85$

Krakue, S. P.

Christ haïtien : Gouverneurs de la rosée et La Bible $\sim 86-93$

Afari, E. S. K. \& Yegblemenawo, C. A. A.

Apports de la télésérie à l'amélioration de la compétence d'expression orale du FLE à l'école normale $\sim 94-116$

Bationo, J.-Cl.

Didactique de la littérature et littérature didactique:

l'exemple de la littérature africaine francophone en classe de langues étrangères au Burkina Faso

Second Section - English

Krakue, S. P.

Quod erat demonstrandum: A comparative study of narrative technique in Ama Ata Aidoo's Changes and Albert Camus'

Les justes (The Just Ones) 〜 $\sim$ $133-141$

Adjandeh, E. A.

Analysis of Wole Soyinka's Trials of Brother Jero in Relation to Ghanaian Religious Discourse $\sim 143-153$

Sam, C. A.

Decolonizing the Postcolony: Of Men, Spatial Politics and the New Nation in WA Thiongo's Wizard of the Crow.

Kambou, M. K. \& Traore, S. A.

Manipulation and the popular uprising in Burkina Faso in 2014. $\sim \quad \sim 172-189$ 
De-Soura, A. Y.M.

Test-taking Strategies of University of Cape Coast Students of

French as a Foreign Language: a Case Study $\sim 191-216$

Kambou, M. K. \& Soma, L.

Local Culture and EFL Vocabulary Learning $\sim \quad 217-238$

Kabore, A. \& Nazortin, C.

Critical Analysis of the Place and Importance of Literature in the Teaching / Learning of English and in School Leaving Certificate Examination in Burkina Faso from 1985 to 2018

Malgoubri, I., Sawadogo, M. \& Kambou, M. K.

Digital Audio-visuals Aids and Listening in English as a

Foreign Language Classrooms

Osei, R. N. \& Inusah, $H$.

A Critique of the Images of Heaven in the Scriptures of the

Abrahamic Religions: An Existentialist Perspective $\sim$ 270- 282

Negedu, A. K.

Lexical Gaps and Ideological Shift in the Translation of

Chinua Achebe's Things Fall Apart as "Le Monde

S'effondre" in French $\sim \sim 283-297$

Talburt, $T$.

Political Transformation and Development in Africa:

Lessons from Achebe's Things Fall Apart

$\sim 298-313$ 


\section{FORWORD}

All the papers in this Volume were presented at a three-day Conference in honour of Professor Atta Gyamfi Britwum who turns eighty years in March 2021. Most of those years he spent at University of Cape Coast, having cut his teeth as a young lecturer in French language and Literature-in-French in 1974. After many years of an illustrious career in teaching, publication and extension, he bowed out at age seventy, but he didn't get the well-deserved rest he was entitled to; he continues to support his Department and the University as a whole. Today, Professor Britwum's name is associated with high standards of professionalism which earned him the nickname 'L'oracle'. Indeed, it is impossible to find another name universally acknowledged as embodying the excellence in French education offered at the Department of French, University of Cape Coast.

The decision to honour Professor Britwum couldn't have been taken at a more appropriate time. It was planned to coincide with the fiftieth anniversary of the publication of the Beautyful ones are not yet Born, Ayi Kwei Armah's first novel. Britwum never grew tired of reading, teaching and examining it. Such was his respect for Armah's craft. So, the three-day Conference was as much a celebration of Armah's contribution to the shaping of the African novel as it was a tribute to Professor Britwum's work as a teacher of literature of immense influence.

One only has to look at the titles of the papers published in this Volume to get an idea of how deep his influence runs at UCC and beyond. Most of the contributors once upon a time sat at the master's feet, but are now scholars in their own right keeping the flame of French scholarship burning bright (George Cooper: "Polished in a high degree, as each froggie ought to be/Now they sit on other logs, teaching other little frogs.") A good number of the papers are on Literature, nonetheless not limited to Armah's works. No Surprise there. Nevertheless, there are Language papers there too. No surprise here either, for the man to whose honour the Volume is dedicated is equally at home in both Language and Literature

\section{Lawrence $K$. Owusu-Ansah,}

Department of English, UCC.

A Disciple 


\section{$A S E M K A:$ EDITORIAL}

This Special Edition of $A S E M K A$, a bilingual literary journal of the University of Cape Coast, is published in honour of Prof. Atta Gyamfi Britwum, a revered Associate Professor of Francophone African Literature and Civilisation in the Department of French, U.C.C. It contains twenty (20) papers centred on diverse areas of teaching and research in the Humanities and on the theme of the Conference - Literature and the Humanities in the 21 Century: Interdisciplinary Perspectives - held in his honour by the Department of French, University of Cape Coast, Ghana, $13^{\text {th }}-15^{\text {th }}$ Mars, 2019. To reflect Prof. Britwum's area of research interest, the essays are arranged in two sections according to his dominant medium of instruction (French language) and speciality (Literature and Civilisation), followed by those in English language. The first section consists of a set of nine (9) essays in French spanning between themes in Literature and Language. The second section is made up of a set of eleven (11) essays in English which examine issues in literary studies, Language and Didactics, ICT and French Education, Philosophy, and Translation, among others. This special arrangement is however representative of the bilingual nature of the Journal.

\section{First Section}

Britwum, A. G.'s paper titled, “Insuffisances Théoriques Des Damnés De La Terre De Frantz Fanon", presents the Fanonian perspective as a complement to the African nationalism that informed anticolonial struggles. The study posits that African nationalism, populist in nature, for failing to target the capitalist economic base, which defines colonialism, ended up strengthening it. It concludes that Fanon's anticolonialist perspective, despite its overt radicalism, is not designed to allow a "bottom-to-top change" in colonial / capitalist society.

Kodah, M. K.'s paper titled, "Disculpation de Dieu dans le malheur des hommes: Une lecture critique de Gouverneurs de la rosée de Jacques Roumain", puts into question the responsibility of God in the suffering of men on earth and the capacity of man to make and unmake himself. The study aims at absolving God of the guilt of the miseries of men, and also questioning the atheistic or anti-religion denunciation of this narrative 
text since its publication. The study is accomplished through a critical reading and a thoughtful analysis of Jacques Roumain's Gouverneurs de la rosée within the analytical structure of literary studies and sociocriticism.

Addo-Danquah, O.'s paper, "Le récit de pensées : Une analyse comparative de Vol de nuit d'Antoine de Saint-Exupéry et La Condition humaine d'André Malraux", drawing inspirations from theorists such as Léon Edel (1961) and later Dorrit Cohn (1981), examines what Antoine de Saint-Exupéry's Vol de nuit by and André Malraux's La Condition bumaine respectively can offer on the side of representations of the interior life. The study is posited within the framework of narratological theories.

Kodah, M. K. \& Togoh Tchimavor, A. A. in "Réactions des femmes face au conflit de genre dans C'est le soleil qui m'a brûlée et Tu t'appelleras Tanga de Calixthe Beyala" examine the reactions of women to gender conflict in Calixthe Beyala's C'est le soleil qui m'a brulée and Tu t'appelleras Tanga. The study critically reflects on the various ways women in Beyala's C'est le soleil qui m'a brulée and Tu t'appelleras Tanga react to oppression and exploitation resulting from patriarchal domination. It therefore examines the sources and nature of this conflict, and how women react to it in the two novels. The study points to the fact that, much as conflict emanating from patriarchal oppression and male's domination in human societies is inimical to the rights of women, the methods used by the latter to free themselves from this state of being remain questionable, in that, these methods defy rational thinking and are also a kind of reversal oppression and domination which are equally unacceptable.

Kudi, M. D.’s paper, “La Littérature francophone face aux médias de télécommunication: Une nouvelle dynamique de la création romanesque, le cas de L'Énigme de retour et Tout bouge autour de moi de Dany Laferrière", seeks to examine how pertinent painting, photography, television, telephone etc. are to the production of the contemporary Francophone novel. The study focuses on L'Énigme de retour (2009) and Tout bouge autour de moi (2011). The analysis is based on the perspective of literary intermediality propounded by Jürgen E. Muller which is characterised by an interaction between telecommunication media and literary text. The study establishes through these selected novels that these media forms are not simply another form of expression in the novel but rather a lens through which the story is narrated. 
Gli, M.'s paper titled, "Les faces du bonheur dans Vol de nuit d'Antoine de Saint-Exupéry", analyses the faces of happiness in Antoine de Saint-Exupéry's Vol de Nuit. The study is conducted through thematic approach. This approach is complemented by Maslow's theory of human needs. The collection of data or the collection of information is purely documentary. The study therefore seeks to establish a link between individual happiness and collective happiness in Saint-Exupéry's selected narrative text.

Krakue, S. P.'s paper, “Christ haïtien : Gouverneurs de la rosée et La Bible", attempts to question Jacques Roumain's Gouverneurs de la rosée in order to elucidate the novelist's use of the biblical text in his creative activity. The study demonstrates that Jacques Roumain's narrative text turns out to borrow biblical ideas not only to develop his plot but also to design his main character.

Afari, E. S. K. \& Yegblemenawo, C. A. A. in “Apports de la télésérie à l'amélioration de la compétence d'expression orale du FLE à l'école normale." examine the impact examine the impact of the use of serial movies as teaching aid on oral expression of French language learners in Colleges of Education in Ghana with the aid of smartphones. The study discovers that the use of serial movies in teaching French boosts learners' performance in oral communication. It therefore recommends that serial movies could be used in teaching French language lessons in order to enhance the oral communication competencies among learners.

Bationo, J.-Cl.'s paper titled, "Didactique de la littérature et littérature didactique : l'exemple de la littérature africaine francophone en classe de langues étrangères au Burkina Faso", shows not only how to teach literature in language class but also how to use didactic literature to develop social skills among learners to reduce vandalism, school violence, negative stereotypes, misunderstandings of intercultural nature while cultivating social peace and living together in a context of internationalization, globalization and digital revolution. The paper focuses on francophone African Literature and posits that methodological approach used for the didactic transpositions of literary content is based on the new orientation and the redefinition of the objectives of language teaching and on the didactic models of the aesthetic reception of didactics of literature which requires putting the learner in intensive interaction with the text and motivating $\mathrm{him} /$ her to express himself/herself on his/her reading experiences. 


\section{SECOND SECTION - ENGLISH}

Krakue, S. P.'s paper titled, “Quod erat demonstrandum: A comparative study of narrative technique in Ama Ata Aidoo's Changes and Albert Camus' Les justes (The Just Ones)", demonstrates through textual analysis, how in Ama Ata Aidoo's Changes and Albert Camus Les justes, the authors resort to a specific form of irony to bring the discussion of issues raised to a conclusion. The technique consists in demonstrating clearly a huge discrepancy between a "fine" idea and its practical usefulness. Both authors successfully use narrative technique. Albert Camus demonstrates the hollowness of the idea of fighting for justice through revolutionary violence and Ama Ata Aidoo similarly demonstrates the fatuousness of the theory of women-emancipation-through-polygamy.

Adjandeh, E. A. analyses selected reports in Ghanaian media in relation to the clergy and identifies how Wole Soyinka's theme is reflected in these media in her paper titled, "Analysis of Wole Soyinka's Trials of Brother Jero in Relation to Ghanaian Religious Discourse". The study seeks to examine the extent to which themes in Soyinka's Trials of brother Jero play out in religious discourses in Ghana. The global nature of the issues problematized by Wole Soyinka also comes out through this study as the work set in Nigeria is analyzed in relation to the selected articles set in Ghana. The paper relies on a content analysis of Trials of Brother Jero and similar themes presented in the selected articles, and makes a few recommendations on how these religious issues could be partially, if not wholly, resolved in Ghana.

Sam, C. A.'s paper, "Decolonizing the Postcolony: Of Men, Spatial Politics and the New Nation in WA Thiongo's Wizard of the Crow", examines how Ngugi Wa Thiongo's Wizard of the Crow blatantly explores Africa's complicity in a seemingly cyclic colonization in the $21^{\text {st }}$ century and its attendant consequences for the total liberation of Postcolonial Africa. The study examines the correlation between masculine representations, spatial reorganization and futurity as alternative ways in thinking about Africa's future through Bakhtin's theory of the carnival and other such concepts as polyphony and the grotesque. The result of the analysis is that the correlation between forms of communities and forms of masculinities is an indication of a vision of hope for Postcolonial Africa. 
Kambou, M. K. \& Traore, S. A. in "Manipulation and the popular uprising in Burkina Faso in 2014", analyse the different discourses in the build-up to the popular uprising in Burkina Faso on the $30^{\text {th }}$ and $31^{\text {st }}$ October 2014. It attempts to clarify how political and civil society leaders use language and other non-linguistic elements to influence the ordinary citizens' minds and, indirectly, their actions. The analysis is premised on Van Dijk's (2006) Sociocognitive approach. The paper analyses the cognitive, the social and the discursive dimensions of manipulation in six political speeches (two speeches from Civil Society, two from the ruling party and two from the political opposition). The results suggest that the three groups manipulated their audiences, and finally, the ruling party lost following the resignation of the then Head of State, making way for a Transition government to take over the reins of governance.

De-Souza, A. Y. M.'s paper “'Test-taking Strategies of University of Cape Coast Students of French as a Foreign Language: a Case Study.” seeks to provide a description of test-taking strategies that may inform teaching and learning of French for better output in tests against the background that Ghanaian students of French as a foreign language deploy strategies that are not adequate enough in answering test items in French. The study examines data gathered right after a French test by level 200 students, using recollective verbalization protocols.

Kambou, M. K. \& Soma, L. examine in their paper titled, "Local Culture and EFL Vocabulary Learning”, the influence of learners' culture on foreign language vocabulary. The paper seeks to demonstrate that there is a link between culture and lexico-semantic errors committed by learners of English as a foreign language among Dioula speaking students in Burkina Faso. A language test composed of two written activities was used as the data collection instrument. The results revealed that the Dioula speakers' English is influenced by their culture. These results have some pedagogical implications. They, therefore, suggest that we adapt the teaching of EFL vocabulary to learners' culture.

Kabore, A. \& Nazortin, C. in "Critical Analysis of the Place and Importance of Literature in the Teaching / Learning of English and in School Leaving Certificate Examination in Burkina Faso from 1985 to 2018", analyse the types of texts given at the "Baccalaureate A" written examination in the last thirty years. In this study, quantitative and qualitative 
data are collected. Baccalaureate written English papers are the main focus of our collection. Teachers and supervisors are interviewed. The study is grounded on "Reader-Response Theory" which stresses the interactions between the reader and the text. The results of the study show that the great majority of texts proposed for "Baccalaureate A" examination, in the last thirty years, are non-literary texts.

Malgoubri, I., Sawadogo, M. \& Kambou, M. K.’s paper titled, “Digital Audio-visuals Aids and Listening in English as a Foreign Language Classrooms", is an experimental study which investigates the potential of digital audio-visuals to improve the listening skills of EFL learners in secondary schools in Burkina Faso. On the assumption that learners born around the year 2000 are digital natives, the researchers try integrating smartphone-friendly audio-visuals in their EFL classrooms in a four-week experiment involving one Experimental Group and one Control Group. The experiment aims at gauging the effectiveness of those aids operated via students' smartphones in improving learners' listening and speaking skills. Independent T-tests were used to compare the groups and Sample Paired TTests to make comparisons within groups. The study suggests that, if appropriately used, smartphones are excellent devices for language teachers and learners in this digitizing world.

Osei, R. N. \& Inusah, H.'s paper, “A Critique of the Images of Heaven in the Scriptures of the Abrahamic Religions: An Existentialist Perspective." Critically examines the scriptural images of heaven as captured in the Abrahamic religions - Judaism, Christianity and Islam - from the existentialist perspective. The paper argues that the idea of life beyond this earthly existence for all human beings in a specially prepared location by God for eternal happiness for those who obey His commands on earth called Heaven, as propounded by the Abrahamic Religions, throws up a lot of problems, especially from the existentialist perspective. The study concludes that the scriptures' constructs of heaven appear self-contradictory and fail to strike a chord with the contemporary image of the ideal society when perused from the existentialist perspective and should, therefore, be discarded.

Negedu, A. K.'s paper "Lexical Gaps and Ideological Shift in the Translation of Chinua Achebe's Things Fall Apart as "Le Monde S'effondre" in French." examines the ideological divergence between the title of the original text and the title of the translation, following an observation 
that in translating Chinua Achebe's Things Fall Apart, Michel Ligny translates directly Igbo terminologies, realities and beliefs into the French language. The paper concludes that the ideology that the translated title projects to French-readers is totally different from the ideology that the original title projects to English-readers.

Talburt, T., in "Political Transformation and Development in Africa: Lessons from Achebe's Things Fall Apart", formulates critical perspectives on the significance of Achebe's novel for the socio-political and economic transformation and development of the African continent. The paper challenges one of the central assumptions in this story that Africa falls apart as soon as it comes in contact with Europe. It questions aspects of political conservatism exhibited in Okonkwo who is suspicious of fundamental changes to his society. The discussion is based on the jollof rice principle of political hybridisation of development which proposes the amalgamation of Westernised and non-Western ideas and systems, in order to achieve economic development, rather than totally rejecting Westernisation in its entirety. The study uses examples of Western-style democracy and State intervention in Africa to demonstrate the significance of embracing some aspects of Westernisation through political hybridisation. 




\title{
La Littérature francophone face aux médias de télécommunication : Une nouvelle dynamique de la création romanesque, le cas de L'Énigme de retour et Tout bouge autour de moi de Dany Laferrière.
}

\author{
Michael Dodzi Kudi \\ University of Cape Coast, Cape Coast, Ghana.
}

\begin{abstract}
Résumé
Le roman (francophone) contemporain cherche à se dépasser, à franchir les frontières sur tous les plans (géographique, culturel, social, linguistique etc.) et surtout à répondre au goût du lectorat du 21ème siècle. Mikhail Bakhtine, dans sa fameuse thèse sur le dialogisme, ouvre la voie vers une meilleure conceptualisation de l'œuvre romanesque en la concevant comme un objet esthétique impur ouvert sur le dehors, un objet artistique qui se réalise avec la conjonction de plusieurs savoirs. Partant de cette conception bakhtinienne du roman, on remarque qu'en dehors d'être un espace où se côtoient plusieurs formes d'expression, plusieurs savoirs et plusieurs langues, le roman francophone devient de plus en plus une plate-forme pour d'autres formes d'expressions artistiques et technologiques telles que la peinture, la photo, le téléphone, la télévision etc. En se basant sur les œuvres de Dany Laferrière, cette étude cherche à examiner en quoi ces médias sont pertinents à la production romanesque francophone contemporaine. L'étude se concentre notamment sur L'Énigme de retour (2009) et Tout bonge autour de moi (2011) et l'analyse des données se situe dans la perspective de l'intermédialité (littéraire) (proposé par Jürgen E. Muller) qui se caractérise comme interaction entre les médias de télécommunication et le texte littéraire. Il se donne à voir à partir de la lecture faite de ces textes de Laferrière que ces formes de medias, ne sont pas simplement une autre forme d'expression dans le roman mais s'imposent plutôt comme miroir à partir duquel le récit est narré.
\end{abstract}

Mots-clés: francophone; interaction; intermédialité; médias; roman; télécommunication. 


\begin{abstract}
The contemporary (Francophone) novel seeks to renew itself, break bounds at various levels (geographical, cultural, social, linguistic etc.) and especially meet the taste of the $21^{\text {st }}$ century reader. In his famous thesis on dialogism, Mikhail Bakhtin opens the way to a better conceptualisation of the novel by conceiving it as an impure aesthetic object, an artistic object which is realised with the collaboration of many voices. With this bakhtinian conception of the novel, it is realised that the Francophone novel, apart from being a space of convergence of many forms of expression, of various knowledge, and languages/voices, is becoming more and more a platform for other artistic and technological expressions such as painting, photography, television, telephone etc. Based on the works of Dany Laferrière, this study seeks to examine how pertinent these media are to the production of the contemporary Francophone novel. The study will focus on L'Énigme de retour (2009) et Tout bouge autour de moi (2011) and the analysis will be based on the perspective of (literary) intermediality (proposed by Jürgen E. Muller) which is characterised by an interaction between telecommunication media and the literary text. A reading of these selected novels reveals that these media forms are not simply another form of expression in the novel but rather a lens through which the story is narrated.
\end{abstract}

Keywords: Francophone; interaction; intermediality; media; novel; telecommunication.

\title{
De l'intertextualité à l'intermédialité littéraire
}

Le dialogisme de Mikhail Bakhtine, qui se caractérise fondamentalement par l'intertextualité et l'interdiscursivité, révèle au monde discursif le dialogue perpétuel et constant qui existe entre les textes et les discours présents, passés et même anticipés. Comme l'explique Todorov (1981:8):

Intentionnellement ou non, chaque discours entre en dialogue avec les discours antérieurs tenus sur le même objet, ainsi qu'avec les discours à venir, dont il pressent et prévient les réactions. La voix individuelle ne peut se faire entendre qu'en s'intégrant au chœur complexe des autres voix déjà présentes. Cela est vrai non seulement de la littérature, mais aussi bien de tout discours $[\ldots]$. 
Au fait, comme il se donne à lire, les discours et voix auxquels fait référence Todorov impliquent également les phénomènes non-verbaux. D’ailleurs, Bakhtine lui-même, dans La Poétique de Dostö̈evski, fait franchir au dialogisme ses frontières d'interaction purement verbale vers le non-verbal en soulignant que :

[...] des rapports dialogiques, au sens large, sont possibles entre d'autres phénomènes de signification, dès lors que ceuxci sont produits par une matière sémiotique. Les rapports dialogiques peuvent exister, par exemple, avec des images prises dans d'autres arts ». (Bakhtine $1970: 242$ )

Il faut signaler que le rapport ou l'interaction qu'un texte (littéraire) peut entretenir avec des images, que celles-ci soient peintes ou photographiées, n'est pas un phénomène récent. Mais la théorisation de ce rapport entre textes et images daterait de quelques décennies. C'est vers la fin du XXème siècle, dans les années 1990 que le théoricien allemand Jürgen E. Müller est devenu l'un des premiers à introduire la notion de l'intermédialité dans le discours critique allemand. Cette théorisation semble être surtout informée par l'émergence, ou plutôt la prolifération des dispositifs de technologie d'information tels que le téléphone, la radio, la télévision, l'internet etc. et l'interaction de ceux-ci avec les textes (littéraires). C'est ainsi que la notion est conçue, et dès ses débuts, s'est perçue comme prolongement de la notion de l'intertextualité. Comme le reconnaît d'ailleurs un des spécialistes du domaine, Remy Benson :

Au départ, il s'agissait entre autres choses, de renouveler les méthodologies mises en place dans les départements d'étude littéraire et de littérature comparée. L'intermédialité visait ainsi à reformuler les enjeux des approches intertextuelles. Si le vocable "texte" entendu dans un sens élargi peut renvoyer à un film, à un son, à une représentation théâtrale ou à une image, son usage est considéré comme symptomatique d'une forme de biais dans l'analyse. L'usage du terme media est alors préféré, car il permet d'insister sur la nécessité de porter une attention plus grande aux caractéristiques techniques de la matérialité de productions culturelles étudiées. ${ }^{1}$

Pour les concepteurs, la notion de l'intermédialité s'impose comme un nécessaire éclatement des frontières des interactions jadis enfermées dans les textes. Dans cette perspective, l'intermédialité vient compléter l'effort des 
théoriciens du dialogisme et de l'intertextualité pour la production de sens. C'est donc avec ce point de vue que Müller le conçoit comme « une nouvelle approche interdisciplinaire $»^{2}$. Il est à remarquer que la nature interdisciplinaire de la notion rendrait ses contours et sa définition difficile à cerner. Pour mieux conceptualiser la notion, Benson propose, à la base de différents médias, quatre axes par lesquels elle peut être appréhendée, à savoir : la coprésence, le transfert, l'émergence, et le milieu :

1/ Si un média est une production culturelle, l'intermédialité peut se donner comme objet d'étudier ce qui se joue entre les différents médias qui constituent cette forme singulière. Le point de vue est alors synchronique. La notion clef à travailler est ici celle de coprésence. 2/ Si un média est une production culturelle, l'intermédialité peut également tenter de saisir la manière dont une forme singulière est liée à d'autres formes qui lui sont contemporaines ou antérieures. Le point de vue est alors diachronique. La notion clef à travailler est ici celle de transfert. 3/ Si un média équivaut à une série culturelle qui a acquis un certain degré d'autonomie, l'intermédialité peut se donner comme objet de comprendre ces dynamiques de distinctions entre médias. La notion clef est alors celle d'émergence. 4/ Si un média correspond à une mise en relation inscrite dans un milieu, les choses se compliquent (encore un peu) puisque ce sont des relations entre des productions culturelles qui créent elles-mêmes du lien qu'il s'agit d'analyser comme constitutives du vivre ensemble. ${ }^{3}$

Ces différents axes proposés par Besson permettent d'aborder la notion en prenant en compte différents paramètres de l'expérience culturelle comme le temps, l'espace, les actants et les interactions qui existent entre eux. Ce qu'il y a à noter dans ces axes c'est l'invasion de l'espace d'un média particulier par un autre. Le processus intermédial assure donc un constant passage de frontière entre les différentes formes d'expression et parfois même, mène à croire que ces frontières entre ces formes d'expression n'existent plus.

C'est justement cet entrecoupement entre les médias qui informe cette étude où il est question d'examiner les échanges qui ont lieu principalement entre les récits de Dany Laferrière et des formes médiatiques. Cette interaction mène, comme le propose Müller, à « un procédé conceptuel dans lequel les relations entre médias sont interrogées et suscitent de nouvelles formes d'expériences médiales pour le récepteur. ${ }^{4}$. Pour mieux cerner notre étude, nous nous intéresserons particulièrement à ce qu'on appelle l'intermédialité 
littéraire, qui renvoie à la convocation par des textes littéraires (comme le roman), d'autres médias (la presse, la photographie, la radio, la télévision, des enregistrements etc.) qui se greffent à eux et interviennent comme suppléments narratifs. Neumann (2015), dans une étude, montre que:

intermediality in literature refers to both the verbal evocation of a distinct medium (be it through explicit thematization of a specific medium or the structural imitation of media-specific forms of world-making) and the direct integration of another medium. As such, intermdiality describes the range of dynamic constellations in which different media run parallel, refer to each other, collide, converge and interact, thus opening up a space of semiotic and material in-between-ness. ${ }^{5}$

Avec ces procédés de l'intermédialité littéraire où des formes d'expression médiatiques soit coexistent, mais surtout s'intègrent au texte littéraire, on assiste à une technique de réécriture, d'une remédiation des médias évoqués à travers le verbal. Le texte littéraire transforme donc les formes d'expressions non-verbales en signes verbaux. Cette forme de transposition fait référence à ce qu'on appelle la novellisation, un procédé d'adaptation d'œuvres médiatiques sous une forme littéraire ou romanesque. Nous nous proposons dans cette étude de voir dans quelle mesure le roman francophone est devenu une plate-forme pour d'autres formes d'expressions artistiques et technologiques telles que la peinture, la photo, le téléphone, la télévision etc. à travers les œuvres de Dany Laferrière, L'Énigme de retour et Tout bouge autour de moi.

\section{L'Énigme du retour: dialogue entre récit et images}

Publié en 2009, L'Énigme du retour est l'histoire d'un homme qui quitte son Haïti natal et vit en exil à Montréal au Canada pendant plusieurs années. Il reçoit un coup de fil qui lui annonce la mort de son père à New York, et se retrouve obligé de retourner dans son pays natal avec la nouvelle du décès. Le roman s'ouvre d'ailleurs sur cet appel téléphonique fatal qui franchit les frontières de loin pour annoncer la mort du père du protagoniste devenant ainsi l'élément déclencheur de l'histoire. À la suite de cet appel, le narrateur, qui doit faire un retour énigmatique au pays natal pour enterrer son père, s'efforce de révoquer les mémoires d'un pays avec lequel il ne s'identifie plus et d'un père avec qui il n'a pas vécu et qu'il n'a pas vraiment connu. La remémoration, la distanciation et le rapprochement entre fils et père ou entre 
citoyen et patrie se font surtout à travers des images photographiques et la peinture.

Du latin 'imago' ou 'imagini' signifiant « qui prend la place de ", l'image est «une représentation abstractive de la réalité » (Paul R Wendt 1952). Elle peut être, selon la typologie de Gervereau, «mentale ou matérielle, fixe ou animée, primaire ou secondaire $»^{6}$. Laferrière, dans L'Énigme $d u$ retour, convoque généralement, par le biais du langage, deux types d'image fixe: la photo et la peinture ou les tableaux. Les théoriciens de l'intermédialité dénomment ekphrasis cette description textuelle de l'image. Comme le souligne Gabriele Rippl: "A demarcated description of a work of visual, either real or imaginary, and not a mode of descriptive writing that is infused with pictoriality, which can be evident in moments throughout the whole text."

Dans ce cas, il ne s'agit donc pas de l'image comme signe visuel mais de l'image comme signe graphique. C'est comme si avec la technique de l'ekphrasis, le travail de l'écrivain visait à simuler la représentation de l'image. Ce phénomène de représentation verbale de l'image, de fondre l'image dans le texte pour que le lecteur puisse percevoir celle-ci avec l'œil de son imagination, brouille les frontières, d'un côté entre image mentale et image matérielle, et de l'autre entre texte et image.

Les atrocités et destructions qui ont marqué le règne dictatorial des Duvalier père et fils entre 1957 et 1986, ont fait de l'image photographique et de la peinture des éléments indispensables à la littérature haïtienne duvaliériste et post-duvaliériste, surtout avec la création romanesque. Dans les textes comme Mûr à crever de Franketienne publié en 1968, Le Briseur de rosée (2005) d'Edwidge Dandicat, Un alligator nommé Rosa (2006) de Marie-Célie Agnant etc., la photo et les tableaux deviennent une partie intégrante de la narration et servent principalement de preuves aux récits narrés. Dans L'Énigme du retour, on retrouve tout au long du texte des images par-ci par-là ; tels qu'un «album de photos rempli de visages souriants» (p. 51), «des centaines de tableaux recouverts de poussière accrochés sur les murs, le long de la rue » (p. 86) où le narrateur interpelle le lecteur à une autre lecture.

La narration semble incapable d'accéder toute seule à la réalité de l'espace et du temps de l'histoire racontée et sollicite le concours de la technologie de l'image et de la peinture pour compenser ce manque. Comme le souligne le narrateur, «cette vieille photo est aujourd'hui mon unique reflet pour mesurer le temps qui passe» (p. 28). Telle qu'elle se présente, «sur le mur une exposition de photos en noir et blanc racontant l'histoire d'un homme et d'une femme dans l'éclat de l'amour» (p. 30), et "Trois salons remplis d'œuvres de peintres haitiens majeurs. Les pionniers : Wilson Bigaud, Benoit Rigaud [...] la génération des Cedor, Lazarre, Luce Turnier [...] et les contemporains comme Jérôme, Valcin » (p. 220), la photo et la peinture sont 
utilisées comme éléments narratifs. Elles se substituent à la narration pour faire revivre au lecteur l'histoire racontée et retracer le passé. L'espace de la narration devient dès lors une plate-forme qui permet de faire appel à toute forme d'expression artistique à participer à la construction du récit. La photo s'arroge le droit ou la fonction de se faire la représentation de la nostalgie et la conciliation avec le passé alors que la peinture participe à l'évocation de la mémoire et de l'identité collectives du peuple haïtien.

Comme chez Laferrière, la photographie et la peinture servent de supports narratifs chez bon nombre d'écrivains haitiens de cette période. Elles servent, à travers leur interaction dynamique avec les récits, de pont entre le passé duvaliériste et le présent (la période post-duvaliériste) chez les uns, ou sont évoquées comme mis en garde et source de libération à la mémoire haïtienne chez les autres. Dans Un alligator nommé Rosa de Marie-Célie Agnant par exemple, le protagoniste, Antoine qui va à la recherche de Rosa (responsable de plusieurs massacres et de la mort du père d'Antoine), prend le soin de rassembler des photos qui font figure de trace des méfaits de Rosa. En effet, "pour accentuer l'authenticité » des atrocités de ce bourreau, Antoine emporte avec lui « une valise pleine de papiers et de photos » qui font revoir (Rosa) en action $»^{8}$. Certaines de ces photos, prises par Rosa elle-même, servent de témoignage à son récit. De ce fait, Rosa semble déjà avoir écrit son récit, ou contribué à engraver ses méfaits dans l'imaginaire haïtien. Les photos permettent d'accéder à la mémoire et deviennent un objet de remémoration.

Au-delà de cette fonction où l'image photographique et la peinture deviennnent la mémoire des protagonistes en se mettant en contact avec un ailleurs spatial et temporel, douloureux ou heureux, c'est encore à travers elles que le narrateur-protagoniste de L'Énigme du retour perçoit son 'Moi' en relation avec celui de son père et de sa patrie, une relation dialogique entre son Moi, celui de son père implanté en lui, et son espace. Cette relation dialogique dans les textes littéraires entre le 'sujet regardé' (la photo) et 'le sujet regardant' (le narrateur-protagoniste)', pour emprunter les termes de Roland Barthes, abonde en littérature haitienne, et Franketienne, un des spécialistes dans le domaine, va jusqu'à faire ranimer le sujet regardé dans la photo pour que celuici interagisse verbalement avec le sujet regardant. En ranimant la photo, Franketienne donne une nouvelle vie à son texte narratif tout en faisant de sa production littéraire une illustration du dialogue qui devait exister entre texte littéraire et d'autres formes d'expression.

Dans L'Énigme du retour, la dialogisation entre image photographiée ou peinte et protagoniste se présente sous des formes diverses. Il y a la description d'« une petite photo où l'on voit mon père avec ma sœur sur ses genoux. Et moi debout à côté de lui [...] Mon père et moi, on a le même visage grave » (p. 204). Non seulement l'image tente de capter les moments d'angoisse du père et 
du fils exilés et victimes du système de répression des Duvalier, mais elle fait l'effort d'évoquer leur ressemblance et d'assimiler l'existence du père à celle du fils. Comme nous le fait lire le narrateur :

Une grande photo en noir et blanc d'un jeune homme qui me ressemble. C'est la seule photo où je les vois ensemble au moment de leur rencontre. Quand je tombe sur cette photo, dit ma mère, j'ai l'impression d'être avec mon fils et non mon mari. $^{9}$

Bien au-delà d'un moment de souvenir, on perçoit, à travers la photo, le retour (énigmatique) du fils, pris comme celui du père, c'est-à-dire que par son retour, le protagoniste réincarne l'image du père. Il est aussi possible de lire dans cette relation qu'établit la photo entre père et fils le rapport du Duvalier père et son règne despotique revigoré par le fils, et dont l'image est devenue une mémoire traumatique pour les haïtiens.

La peinture pour sa part fait un effort d'évoquer cette relation dialogique entre le narrateur-protagoniste et son espace à travers la représentation de la mémoire traumatique haïtienne à l'envers. La preuve de cette affirmation, on la retrouve dans les lignes suivantes:

Des centaines de tableaux recouverts de poussière accrochés sur les murs, le long de la rue. On les croirait peints par un seul et même artiste [...]. Les mêmes paysages luxuriants reviennent pour dire que l'artiste ne peint pas le pays réel mais bien le pays rêvé. J'ai demandé à ce peintre aux pieds nus/ pourquoi il peint toujours ces arbres croulant/ sous les fruits lourds et juteux/ alors que tout est désolation autour de lui. / Justement, me faitil avec un triste sourire, / qui veut accrocher dans son salon/ ce qu'il peut voir par la fenêtre ${ }^{10}$

Les enjeux que présentent ces tableaux en question sont très éloquents pour la situation que vit la société haïtienne dans la mesure où ceux-ci se présentent comme une ironie de la situation de vie haïtienne, un vécu qui s'assimile à un "fleuve de douleur dans lequel on se noie en riant", ou à une "Tête fière/ Ventre creux» (p. 84). Le narrateur-protagoniste qui ne se retrouve pas dans son propre espace se sert de la peinture pour se distancier de cette réalité haïtienne d'où l'impossibilité de son retour.

À cet égard, la photo et la peinture deviennent la mémoire même du texte narratif qui, à son tour, comme «le visage [du] père qui ne peut s'animer sans la voix de (la) mère » (p. 38), prête sa voix ou ses mots à celles-ci pour 
qu'elles puissent se raconter. La narration se négocie entre le textuel et le visuel dans une juxtaposition de deux univers qui se construisent l'une à travers l'autre. Il se révèle donc un transfert de valeurs, du textuel vers le visuel à travers la description, et du visuel vers le textuel, la narration. De l'évocation du visuel fixe dans L'Énigme, Laferrière passera au visuel mobile dans son prochain roman, Tout bouge autour de moi.

\section{Tout bouge autour de moi : à travers l'œil de la caméra}

Publié en 2011, deux ans après L'Énigme du retour, Tout bouge autour de moi relate les événements du séisme qu'a subi Haïti en 2010. Le narrateur, qui se retrouvait dans son pays natal au moment du séisme avec quelques-uns de ces collègues écrivains dans le cadre d'un festival littéraire, essaie de nous faire part de ses expériences avant, pendant et après le phénomène. Incapable de saisir la réalité de ce tremblement de terre à cause du choc et du dégât traumatique qui en sont les conséquences, et surtout à cause de son expérience limitée, le narrateur fait recours à un dispositif médiatisé. En effet, c'est surtout le dispositif intermédiatique de la télévision qui devient l'un des angles de perception de la narration. C'est parfois par sa focalisation qu'une partie des événements est racontée.

L'effort que fait le narrateur de collecter des informations sur le phénomène à travers des médias de télécommunication se voit dès le début du récit :

La radio fonctionne. Je cherche à avoir des nouvelles des autres quartiers de la ville. On voudrait bien connaitre l'étendue des dégâts. J'entends soit un grésillement, soit une émission préenregistrée. En tâtonnant, je tombe sur RFI (Radio France International) $[\ldots] .^{11}$

Tout au long du récit se voit cet effort incessant que font les personnages et le narrateur lui-même à se renseigner sur les dégâts causés par le séisme à travers «les radios [...] (qui) crachotent l'horreur. L'internet (qui) fonctionne par intermittence [...]. Les téléphones (qui) ne marchent pas encore » (p. 81), la télé où, «les images défilent en silence [...]» (p. 98) et «Wikipedia (qui) avait annoncé (la) mort » du narrateur (p. 99).

Tout cet effort continu donne à lire comment l'espace narratif est envahi par les dispositifs de télécommunication qui s'imposent au récit comme instances narratives et présentent au lecteur une façon composite d'appréhender l'univers narratif. Le narrateur de Laferrière qui semble s'effacer devant les dégâts du séisme compte tenu de son incapacité de dire l'horreur, se 
réfugie dans ces dispositifs médiatisés et fait place à une focalisation multipliée qui est, à la fois, ici et ailleurs, proche et lointain, partout et nulle part. Il se trouve qu'à un moment donné du récit, le narrateur était obligé de quitter le pays natal, Haïti pour Montréal, son pays adoptif. Se trouvant donc éloigné du lieu de l'événement, le narrateur perçoit et raconte le reste de la péripétie de ce phénomène catastrophique avec un regard lointain. Ainsi, en dehors de la radio et des photos prises par des photographes, c'est surtout par la caméra de télévision que le narrateur fait part au lecteur de cette partie de son témoignage du séisme après son départ :

Déjà à l'arrivée, à Dorval, la télé était là. Les questions fusaient dans tous les sens et je découvrais mon ignorance de la situation. En Haïti, on n'avait pas assez de recul pour voir tout le paysage. On ne pouvait s'occuper que de ses voisins immédiats. On ignorait ce qui se passait dans les autres quartiers de la ville [...]. Si en Haïti on vit tout cela en direct, à l'étranger on le voit. Le petit écran ne cligne jamais de l'œil. Il regarde tout $[\ldots]$. Je suis prostré dans mon lit et ne cesse de regarder défiler sous mes yeux ces images d'épouvante, ne pouvant croire que je viens tout juste de quitter ce paysage dévasté. $^{12}$

Le récit télévisé prend charge de la narration et présente, comme extension, une version médiatisée de ce que le narrateur a vécu. Cette disposition où les événements d'un récit fictif parviennent aux lecteurs à travers l'œil de la caméra ou de la télévision peut à juste titre se caractériser comme la 'technologisation' du récit fictif. L’intégration de la télévision au récit permet au narrateur-protagoniste non seulement de se remettre en voyage imaginaire vers son ailleurs, Haït, qu'il venait de quitter, mais aussi de placer le lecteur devant une nouvelle expérience. Sa perception des événements du récit raconté ne passe plus seulement par l'imaginaire du texte mais aussi par celui du dispositif télévisé, voire la combinaison des deux.

Le récit, ainsi raconté à travers un regard autre de l'écran, faisant du medium télévisé un point de vue narratif, oscille le texte littéraire entre récit réel, testimonial, mémoriel et médiatisé. L'interaction entre média et narration permet, dès lors, au narrateur de combler ces trous de mémoire. Ainsi, comme l'image photographique et la peinture qui prennent charge d'une partie de la narration de L'Énigme du retour, la caméra de télévision devient une passeuse de mémoires et garante de l'imaginaire haïtienne que le texte narratif seul se trouve incapable de faire. 
En guise de conclusion, il convient de souligner que l'incorporation de l'image (photo et peinture) et du dispositif télévisuel par Dany Laferrière dans ces œuvres, permet un éclatement de celles-ci. Les textes ne s'enferment pas dans les mots comme a jadis été le cas. Ils deviennent une superposition de diverses formes d'expression, voire, de voix narratives qui rendent ces textes beaucoup plus expressifs. La photo, la peinture et la télévision deviennent une autre manière de pousser le lecteur à un autre effort de lecture. Cet effort le mène (le lecteur), à ne plus lire pour déchiffrer les mots, mais lire pour se représenter l'action et le monde à travers les formes d'expression technologisées qui ont envahi l'espace narratif aussi bien que son espace réel. La lecture finit par devenir une représentation iconique de l'événement. Le fait d'insérer l'image picturale dans l'imaginaire fictif donne à l'intermédialité une autre forme de réalisme qu'on peut appeler le réalisme de l'imaginaire. Cette incorporation des éléments réels à l'imaginaire mène non seulement à briser la frontière entre le réel et le fictif, mais vise à rendre le récit beaucoup plus réaliste.

\section{Notes}

1. Besson, B. (2014). Prolégomènes pour une définition de l'intermédiarité à l'époque contemporaine. In Hal, Archives ouvertes. Consulté le 2 Avril, 2017 de https://hal.archives-ouvertes.fr/hal01012325v1/document.

2. Müller, J. E. (2000). L'intermédialité, une nouvelle approche interdisciplinaire : perspectives théoriques et pratiques à l'exemple de la vision de la télévision. In Cinémas, Vol. 10, No. 2-3. (p. 105-134).

3. Besson, R. Ibid.

4. Cité par Thiers, B. (2012). Penser l'image, voir le texte. L'intermédialité entre histoire de l'art et littérature. In La Vie des idées. Consulté : le 15 novembre, 2015 de http://www.laviedesidees.fr/Penser-l-image-voirle-texte.html.

5. Neumann, B. (2015). Intermedial Negotiations: Postcolonial literatures. In Rippl, G. (Ed.) Handbook of Intermediality: Literature - Image - Sound Music. Berlin : De Gruster. (p. 512 - 529).

6. Voir: Gervereau, L. (2016). Le Regard du sens. Paris: Bulletin des Bibliothèques de France. Ressource en ligne. Consultée : le 12 octobre, 2016 de http://bbf.enssib.fr/consulter/03-gervereau.pdf.

7. Cité par Karastathi, S. (2015). Ekphrasis and the Novel/Narrative Fiction. In Rippl, G. (Ed.) Handbook of Intermediality: Literature - Image Sound-Music. Berlin : De Gruster. (p. 92 -112).

8. Agnant, M.-C. (2006). Un alligator nommé Rosa. Montréal: Remueménage, p.62. 
9. Laferrière, D. Op. Cit., p. 205.

10. Ibid, p. 86.

11. Laferrière, D. (2011). Tout bouge autour de moi. Montréal: Mémoire d'encrier, p. 36.

12. Ibid, p. 95.

\section{Références}

Agnant, M.-C. (2006). Un alligator nommé Rosa. Montréal : Remue-ménage.

Bakhtine, M. (1970). La Poétique de Dostoïveski. Paris : Seuil.

Besson, R. (2014). Prolégomènes pour une définition de l'intermédialité à l'époque contemporaine. Hal, Archives ouvertes. Consulté : le 2 Avril, 2017, de https://hal.archives-ouvertes.fr/hal-01012325v1/document.

Barthes, R. (1995). Euvres complètes tome III 1974-1980. Paris : Seuil.

Franketienne. (1968). Mûr à crever. Port au Prince : Editions Mémoire.

Gervereau, L. (2001). Le Regard du sens. Paris: Bulletin des Bibliothèques de France. Ressource en ligne. Consultée: le 12 octobre, 2016, de http://bbf.enssib.fr/consulter/03-gervereau.pdf.

Karastathi, S. (2015). Ekphrasis and the Novel/Narrative Fiction. In Rippl, G. (ed.). Handbook of Intermediality: Literature - Image - Sound - Music. Berlin: De Gruster. (p. 92 - 112).

Laferrière, D. (2009). L'Énigme du retour. Montréal : Boréal.

Laferrière, D. (2011). Tout bouge autour de moi. Montréal : Mémoire d'encrier.

Müller, E. J. (2000). L'intermédialité, une nouvelle approche interdisciplinaire : perspectives théoriques et pratiques à l'exemple de la vision de la télévision. In Cinémas, Vol. 10, No. 2-3. (p. 105-134).

Müller, E. J. (2006). Vers l'intermédialité : histoires, positions et options d'un axe de pertinence. In Mediamorphose, No. 16. (p. 105-106).

Neumann, B. (2015). Intermedial Negotiations: Postcolonial literatures. In Rippl, G. (ed.). Handbook of Intermediality: Literature - Image - Sound Music. Berlin : De Gruster. (p. 512 - 529). 
Thiers, B. (2012). Penser l'image, voir le texte. L’intermédialité entre histoire de l'art et littérature. In La Vie des idées. Consulté : le 15 novembre, 2015, de http://www.laviedesidees.fr/Penser-l-image-voir-le-texte. html.

Todorov, T. (1981). Mikhaïl Bakbtine, le principe dialogique (suivi de) Écrits du Cercle de Bakbtine. Paris : Seuil. 
